\title{
CONSERVATION OF GRASSLAND HABITATS BIODIVERSITY IN THE CONTEXT OF SUSTAINABLE DEVELOPMENT OF MOUNTAIN AREA OF ROMANIA
}

\author{
COJOCARIU, L. ${ }^{1,2}-$ COPĂCEAN, L. ${ }^{1 *}-$ POPESCU, C. ${ }^{1}$ \\ ${ }^{1}$ Banat's University of Agricultural Sciences and Veterinary Medicine "King Mihai I of \\ Romania" from Timisoara, 300645, 119, Calea Aradului, Timisoara, Romania \\ (phone: +40-0256-277-009; fax: +40-0256-200-296) \\ ${ }^{2}$ Centre for Mountain Economics, "Costin C. Kiritescu” National Institute for Economic \\ Research, Romanian Academy, 725700, Str. Petreni, nr. 49, Vatra Dornei, jud. Suceava, \\ Romania \\ (phone: +40-3301-10-030; fax: +40-3301-10-030) \\ *Corresponding author \\ e-mail:lorecopacean@yahoo.com; phone:+40-0729-591-651
}

(Received $17^{\text {th }}$ Mar 2019; accepted 22 ${ }^{\text {nd }}$ May 2019)

\begin{abstract}
The aim of the study was to analyze grassland areas in relation to the activities and financial support schemes dedicated to the conservation of grassland habitats, with a view to sustainable development of Romania's mountainous area. A multitask analysis was carried out: the geomatic approach of pastoral space and its relations with other environmental components, having "localized" results in space and therefore the possibility of intervention "from the general to the specific". The grasslands cover $22.30 \%$ of the Romania's mountainous area, a percentage which gives them a special importance. The large number of identified protected areas (770 entities of different categories) support the idea of the high biodiversity of the mountainous area, implicitly of the grassland habitats. One third of grassland areas $(36.65 \%)$ are included in one or more environmental protection structures. In addition to biodiversity conservation measures imposed by different protected areas, Romania's mountainous area is fully included in the Agro-Environment and Climate and Ecological Agriculture programs, part of the Common Agricultural Policies, which encourages the pursuit of sustainable agriculture, also the protection of biological resources. This study encouraging and sustaining extensive traditional agricultural practices, determines both the maintenance of biodiversity and the diversity of semi-natural grassland habitats.
\end{abstract}

Keywords: analysis, geomatics, pasture, protection, financing, management

\section{Introduction}

The political, social, economic and environmental context of the last century has generated changes and, at the same time, complex and synergistic challenges for the real preservation of nature. For example, changes in livestock and the reorganization of agricultural land have a negative and/or positive impact on natural and semi-natural pastures and on traditional landscapes in agriculture, the relationship being possible on the reverse (Baessler and Klotz, 2006; Garnier et al., 2007; Ceballos et al., 2010; Căluşeru et al., 2015). On the other hand, efficient management of grasslands requires the adoption of strategies according to local conditions in order to respond to the context of reality. In this interaction, managers in protected areas and nature conservation institutions, along with the agricultural sector, have a very important role (Balázsi, 2017). In the territory, the installation of protected areas imposes certain rules 
and behavior regarding the exploitation of grasslands, which, besides the protection of environmental factors, also aims at preserving biodiversity.

Protected areas, seen as "the key to mitigating climate change, preserving biodiversity, providing ecosystem services and promoting human well-being" (Vega et al., 2017) have seen an upward path in their space-time evolution. Thus, the surface of the globe in the 1990s was "protected" in a proportion of 8.6\%, in 2016 this area rising to $14.7 \%$ and includes land and estuary ecosystems with the exception of Antarctica (Vega et al., 2017).

The need to set up and extend protected areas is based on a holistic approach, seen at global level and has grown as a result of increased risks generated by climate change (Ruiz-Mallén et al., 2015), concern for the environment (Wandersee et al., 2012), more and more severe deforestation (FAO, 2010) and installation of non-specific or invasive vegetation (Lei et al., 2014), major risks to produce "hydrological" disasters such as floods (Saraswati, 2014) and "unburned" floods, the uncontrolled expansion of urban spaces (McDonald, 2013; López Lambas and Ricci, 2014), in the face of biological formations.

Before 1989, Romania's territory was "protected" by different types of protected areas, at a rate of 4.1\% (Iojă et al., 2010). After 2000, interest in protected areas increased significantly; under the pressure of joining the European Union, legislative and normative regulations have been introduced to "extend" the existing protected areas (Geacu et al., 2012). After joining the EU, Romania had to expand its "protected territory" to $17 \%$ of the total, making it "joining" the Natura 2000 European Network (Bălteanu et al., 2009).

In 2014 , in Romania the protected areas covered $24.84 \%$ of the country's territory (protected natural areas, 7\% and Natura 2000 sites, 17.84\%), being registered: 79 scientific reserves; 13 national parks; 230 monuments of nature; 661 nature reserves, 15 natural parks; 19 Ramsar sites; 3 Biosphere Reserves; 1 World Heritage Site, respectively the Danube Delta (Antonescu et al., 2015).

Declaring a "protected area" has effects on the entire geosystem, depending on its size and profile. There are situations like these (Antonescu et al., 2015): the extension of areas to other areas which do not require protection, initially with other destinations; human settlements located near protected areas are usually underdeveloped and with limited development opportunities, with restricted access to infrastructure, leading to population migration and therefore demographic imbalances.

The management of grasslands from the protected areas is not always economically and socially correlated with the objectives and needs of communities in the deprived areas (Molnár et al., 2016). On the other hand, the "establishment" of the protected areas ensures: preserving biodiversity, attracting european funds and developing projects with multiple benefits, preserving local and regional traditions.

Regarding the use of grasslands in Romania, besides the protective measures imposed by different categories of protected areas, there are several relevant instruments of the Community Agricultural Policy (CAP): direct payments, milk quota, sustainable rural development (Pillar 2 measures) such as investment aid, agri-environmental measures (EMA) and support for mountain areas (Osterburg et al., 2010). Moreover, the $\mathrm{CAP}$ has established rules to maintain traditional grassland management through eligibility rules and minimum requirements as a prerequisite for receiving direct payments. 
Exploiting grasslands under the socio-economic and cultural conditions of mountain areas in Romania, has long been and is in most cases in line with the principles and rules imposed by the presence of protected areas or CAP policies, not due to "environmental culture", but relied on the basis of financial and technical underdevelopment. Contrary to intensive farming practices, in the mountain environment, through physic-geographic traces and pastoral culture, some of the principles of sustainable agriculture meet, which place the environment and its resources at the forefront.

Concerns about the sustainability of mountain farming and the conservation of grassland habitats' biodiversity are expressed in numerous researches (Öllerer, 2012; Păcurar et al., 2015; Cojocariu et al., 2018), under various theoretical and applicative aspects, context in which the researches presented in this paper are included.

In this context, the aim of the study was to analyze grassland areas in relation to the activities and financial support schemes dedicated to the conservation of grassland habitats, with a view to sustainable development of Romania's mountainous area. At the same time, we want to answer a number of questions: "Where are conservation measures applied? What are the relationships between conservation structures? What are the implications for environmental protection in the organization of the geographical space and especially of the agricultural space".

With the first stage of the documentation on the theme, we have drawn attention to another topical topic, especially in our country, namely the sustainable agriculture, functionally linked to the action of nature conservation. Under these conditions, we attempted to formulate scientifically reasoned answers also to the questions: "Under what conditions can sustainable agriculture be practiced on the pastures in the mountainous area of Romania?" or "Is there financial support for sustainable agriculture?".

The choice of the study area was based on the idea that the mountain area, extended over a third of the entire territory of Romania, represents an area with great biological diversity and the most complex ecosystems, but also a "step-by-step" territory for its inhabitants, from socio-economic point of view, despite the availability of natural resources. Of all the natural resources of the mountain range, grasslands can be regarded as "everyone's reach" with minimal operating costs (compared to forests or arable land) available on large and renewable surfaces under appropriate use conditions. These sometimes contradictory aspects have stimulated us and lead us to the deepening and detailed analysis of the pastoral area of Romania's mountainous area, important both at national and European level.

Being a multidisciplinary work, a multitask analysis was carried out: the geomatic approach of pastoral space and its relations with other environmental components, having "localized" results in space and therefore the possibility of intervention "from the general to the specific"; we also analyzed the conditions under which European programs for nature conservation and changes in agricultural practices can be applied. The study draws attention to the conservation status of biodiversity at present and can be used as a basis or model for other research as well as for the development of future strategies for the mountainous area of Romania and the graphic and non-graphic database can be reused, completed or "rearranged" according to new needs. 


\section{Work methodology}

\section{Study area}

The area analyzed in the present paper is equivalent to the Mountain Area defined in the National Rural Development Program 2014 - 2020 - NRDP 2014 - 2020 (MARD, 2019) as being the sum of the areas of the administrative-territorial units (ATU) located at average altitudes greater than or equal to $600 \mathrm{~m}$ and of the units located at an altitude of $400-600 \mathrm{~m}$, but with average values of slopes higher than or equal to $15 \%$. Under these conditions, the study area includes the Carpathian area, but also the adjacent areas, Sub-Carpathians, plateaus and high hills (Fig. 1).

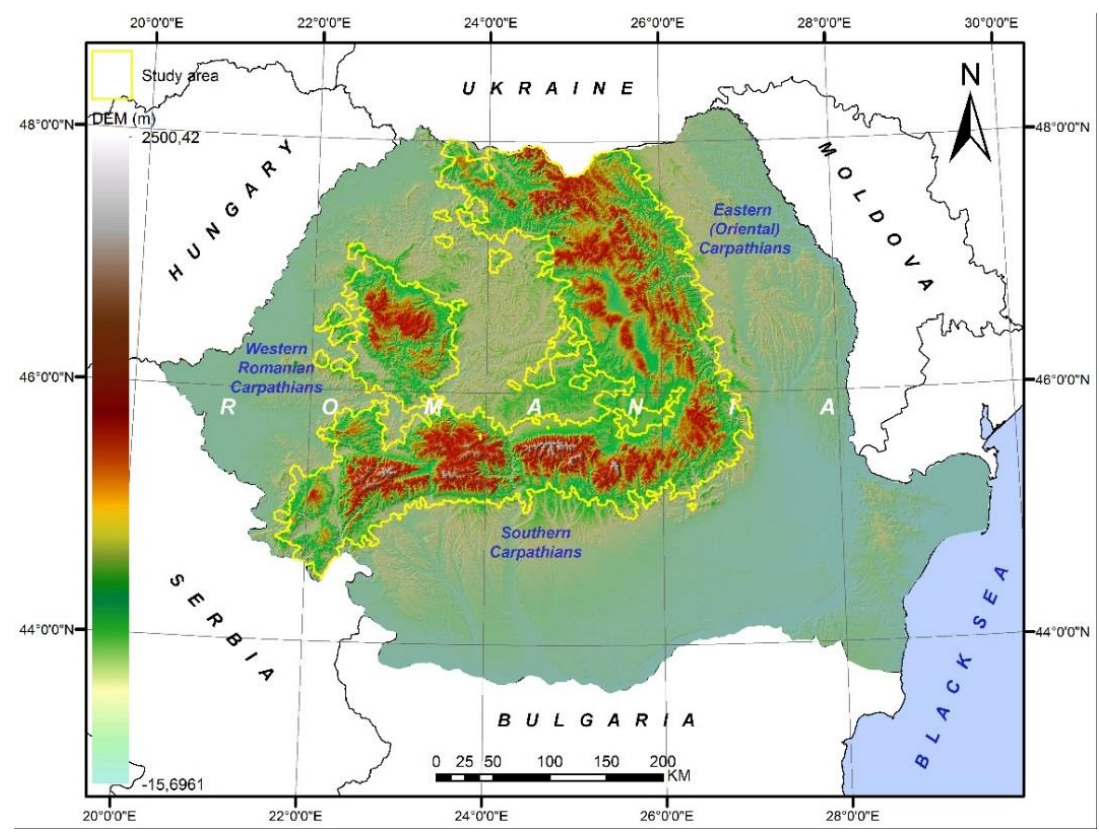

Figure 1. Location of study area. (processing according to EEA, 2017; MARD, 2019; NACRA, 2019)

Based on these considerations, the study area with a semi-administrative or semiphysical delimitation comprises 658 ATUs with a total area of 7143943.38 ha (NACRA, 2019), $71439.43 \mathrm{~km}^{2}$ respectively, being more extensive than the area of the Carpathian Mountains on the territory of Romania, physically and geographically delimited, with the area of $69872 \mathrm{~km}^{2}$ (Dumitraşcu et al., 2015).

\section{Materials and methods}

The four-step systematized research methodology, as well as the materials used in the study, are presented in Figure 2. Scientific data and information has been processed and interpreted with the ArcGIS 10.2.1 software, which has also been used to generate cartographic materials.

1. The analysis of grassland surfaces from mountain areas has been based on the Corine Land Cover Database, edition 2012 (EEA, 2012), a program coordinated by the European Environment Agency and part of the Global Monitoring for Environment and Security program, data available on the European Environment Agency website. The database was updated in 2018 by comparison with aerial images (Google Earth 
platforme, 2018) and data from the National Institute of Statistics of Romania - Land surface by mode of use, by counties and localities (NIS, 2018).

Of the Corine Land Cover Database (EEA, 2012), a total of 26930 entities (all land use categories) were analyzed, and the "grassland" category, interest in this study, with an area of 1593461.64 ha, included: secondary pastures (code 231), with a total of 4474 entities and a total area of 665494.35 ha and natural grassland (code 321), with a total of 2628 entities and a total area of 503622.83 ha. To the two "clear" categories, we may add pastures and hayfields (including wooded pastures), "recovered" from other categories: agricultural land with significant areas occupied with natural vegetation (code 243), agro-forest land (code 244), and bushy vegetation (code 322, 323, 324).

After the identification and framing of each unit, by means of the "joining" procedure (the Merge command), the map of the grassland distribution in the mountain area was obtained in unitary vector format.

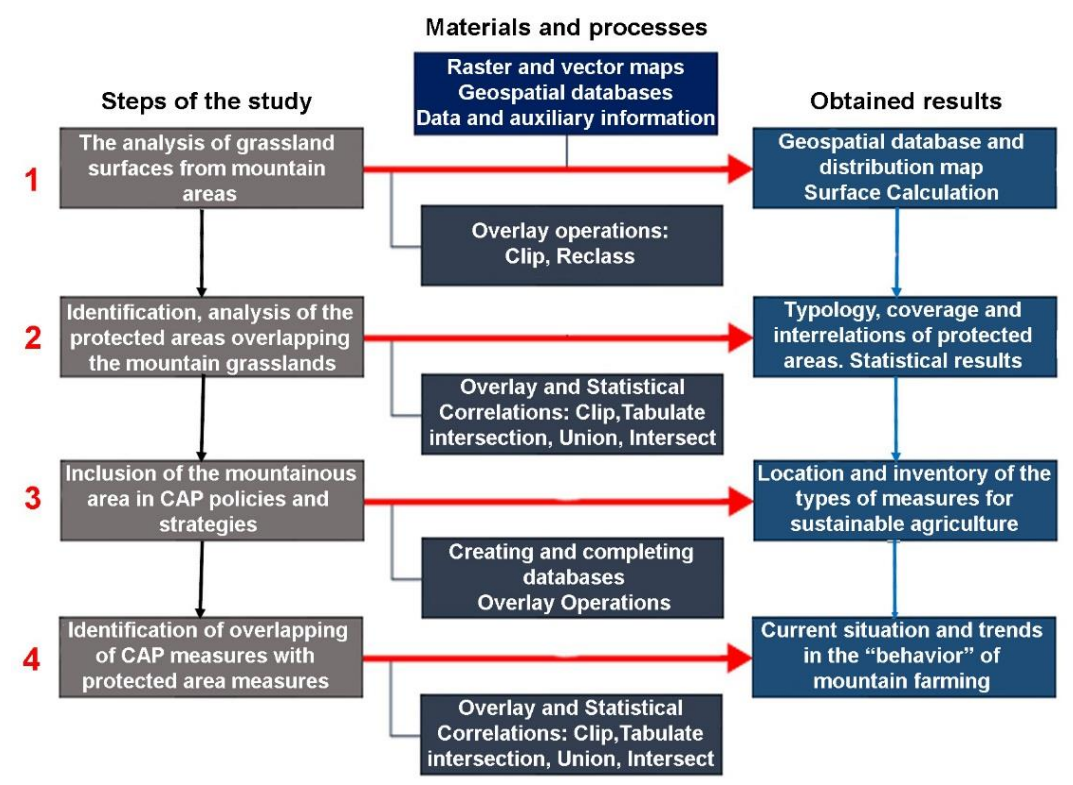

Figure 2. Methodology of research

2. The identification and analysis of the protected areas overlapping the grasslands in the mountain area was based on the vector format file with their geometry published on the website of the Ministry of the Environment, in 2017.

In the mountain area, 770 protected areas of different categories were identified, covering a total surface of 4862584.44 ha. Inventory and analysis of protected areas covered all categories of protected sites in the area of interest, both national and international. The "Protected Areas" layer database has been hierarchically structured and categorized.

For each category, we calculated the area and the percentage within the mountain area, and analyzed, as percentage, the situation of the overlapping (Tabulate Intersection function), thus calculating the intersection with other areas. Subsequently, the spatial correlation with the grasslands (the Union function) was made to determine the "degree and form" of the protection imposed.

3. The inclusion of the mountainous area in CAP policies and strategies was supported by the documentation from NRDP 2014-2020 (MARD, 2019). For each of 
the 658 ATUs, we associated descriptive information (database completion) related to applicable programmes in the case of grasslands (Agro-Medium and Climate and Ecologic Agriculture). After spreading the funding strategies, the overall image and regionalization was outlined.

4. The identification of overlapping areas of CAP measures with protected area specific measures was done through multilayer operations, overlapping and unification of the two databases, resulting in the overall situation of supporting sustainable agriculture.

Working procedures in the GIS (Geografic Information Systems) environment were applied according to technical specifications for ArcGIS 10.2.1 software and ESRI documentation.

\section{Results and discussions}

\section{Grassland fund from the mountain region of Romania}

The grasslands of Romania's mountainous area, one of the most important natural resources, multifunctional and with deep historical references, are "indispensable" to the inhabitants of these areas, being among the few sources of income and can therefore be treated as "support of subsistence".

The grasslands total 1593461.64 ha, respectively $22.30 \%$ of the total area of Romania's mountainous area (defined according to MARD, 2019), which are present in all forms and relief units, ranging from river meadows to high mountain areas (Fig. 3).

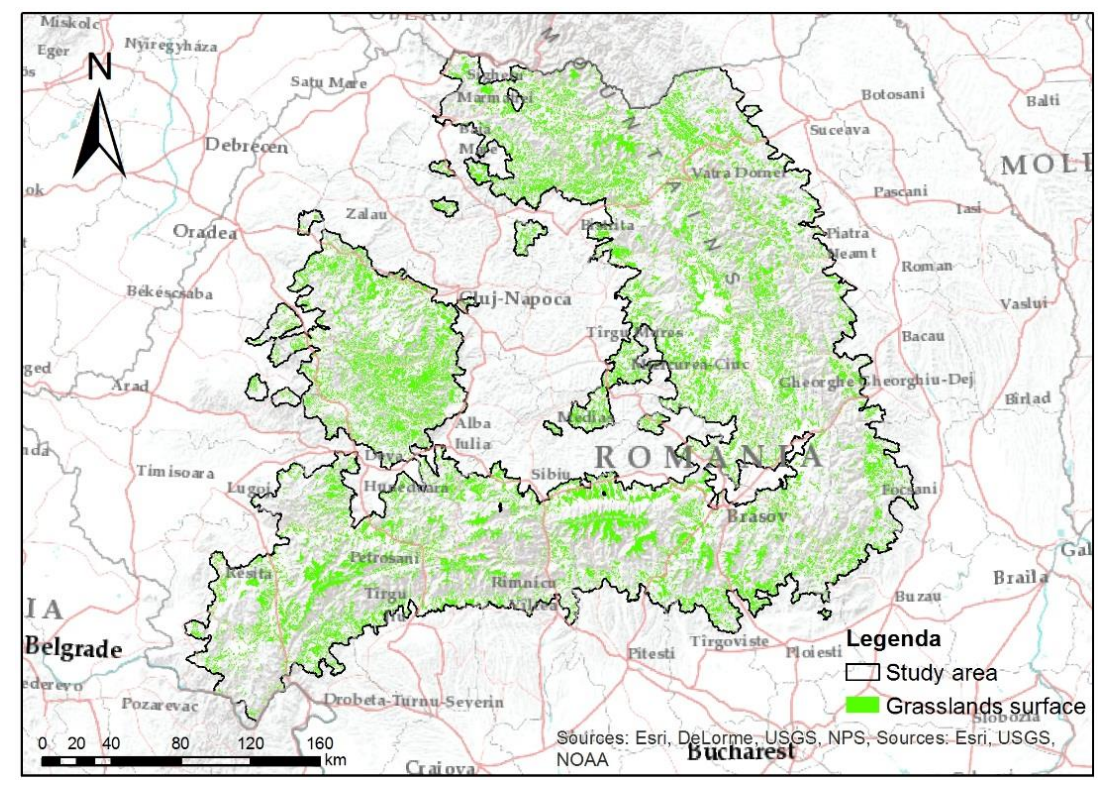

Figure 3. Distribution of grasslands in the mountainous area of Romania. (processing after EEA, 2012; MARD, 2019)

\section{Biodiversity conservation structures (Protected areas) in mountain areas, with special reference to the areas used as grasslands}

At the level of the mountain area, the protected areas were grouped into 10 categories, presented in Table 1. 
The statistical data show that Natura 2000 sites have the largest expansion, with $75.62 \%$ of the total protected areas, followed by the Protected Areas of National Interest, with a share of $21.45 \%$ of the total. Biosphere reserves and Wetlands of international Importance have a reduced share of less than $2 \%$ each (Table 1).

Table 1. Type and surface of protected areas from mountain region*

\begin{tabular}{c|c|c|c|c|c|c}
\hline \multirow{2}{*}{ No. } & \multirow{2}{*}{ Membership } & \multirow{2}{*}{ P.A. type } & \multirow{2}{*}{ No. entities } & \multicolumn{2}{|c|}{ Surface } & \multirow{2}{*}{$\begin{array}{c}\text { of M.A. } \\
\text { surface }\end{array}$} \\
\cline { 5 - 6 } & & & & ha & \% of total P.A. & SCI \\
\hline 1 & \multirow{2}{*}{ Natura 2000 Sites } & 181 & 2174706 & 44.72 & 30.44 \\
2 & SPA & 50 & 1502658 & 30.9 & 21.03 \\
\hline 3 & N.P. & 12 & 298152 & 6.13 & 4.17 \\
4 & n.p. & 10 & 560572 & 11.52 & 7.84 \\
5 & Protected Areas of National & M.N. & 1 & 8 & 0.0001 & 0.0001 \\
6 & Interest & S.R. & 2 & 43 & 0.0008 & 0.0006 \\
7 & & N.R. & 27 & 19134 & 0.42 & 0.26 \\
8 & & RONPA & 482 & 164661 & 3.38 & 2.30 \\
\hline 9 & Biosphere Reserves & ROMAB & 2 & 85518 & 1.76 & 1.19 \\
\hline 10 & Wetlands of International & RORMS & 3 & 57127 & 1.17 & 0.79 \\
\hline
\end{tabular}

Legend: PA-Protected Areas, MA-Mountain area, SCI-Sites of Community Importance, SPA-Special Protection Areas, NP-National Parks, np-Natural Parks, MN-Monuments of Nature, NR-Natural Reserves from IUCN IV Category, RONPA Natural Reserves, SR-Scientific Reserves, ROMABBiosphere Reserves, RORMS-Wetland of International Importance.

* data extracted from the geospatial database published on the website of Ministry of the Environment, 2017

National Parks, declared structures to protect nature's wildlife are materialized in 12 entities (Table 2) and are the most "restrictive" structures that "dictate" the conservation measures in overlapping areas, irrespective of the presence of other protection entities (Ministry of the Environment, 2000; Stanciu and Florescu, 2009) and were identified on a small area, $4.17 \%$ of total.

Table 2. National parks superimposed on the mountainous area of Romania*

\begin{tabular}{c|c|c|c|c|}
\hline No. & National Park (NP) & Code & Founded & Location in the mountain area \\
\hline $\mathbf{1}$ & NP Buila Vânturariţa & RONPA0848 & 2004 \\
$\mathbf{2}$ & NP Călimani & RONPA0009 & 1990 \\
$\mathbf{3}$ & NP Ceahlău & RONPA0008 & 1955 \\
$\mathbf{4}$ & NP Cheile Bicazului-Hăşmaş & RONPA0007 & 1990 \\
$\mathbf{5}$ & NP Cheile Nerei-Beuşniţa & RONPA0003 & 1990 \\
$\mathbf{6}$ & NP Cozia & RONPA0010 & 1990 \\
$\mathbf{7}$ & NP Defileul Jiului & RONPA0933 & 2005 \\
$\mathbf{8}$ & NP Domogled-Valea Cernei & RONPA0001 & 1990 \\
$\mathbf{9}$ & NP Munţii Rodnei & RONPA0005 & 1990 \\
$\mathbf{1 0}$ & NP Piatra Craiului & RONPA0011 & 1990 \\
$\mathbf{1 1}$ & NP Retezat & RONPA0002 & 1988 & \\
$\mathbf{1 2}$ & NP Semenic-Cheile Caraşului & RONPA0012 & 1990 & \\
\hline
\end{tabular}

* data extracted from the geospatial database published on the website of Ministry of the Environment, 2017 
Mathematically, by summing up the areas of all the protected areas, their total area in the mountain area is 4862584.44 ha $(68.05 \%)$, but in a more detailed analysis, these entities overlap in many cases on the same territory, which invalidates the information and suggests the Overlay approach, in which each layer is analyzed in correlation with the others.

Thus, the statistical calculations show that the total area of the protected areas, the horizontal "footprint" on the surface of the mountain area, irrespective of the number of protected areas overlapped vertically, is 2737574.06 ha, which represents $38.32 \%$ of the total area of the area mountain.

The results of the spatial correlation of protected areas - grasslands indicate that 584104.86 ha $(36.65 \%)$ of the total area of mountain grasslands is under the protection of different categories of sites for biodiversity conservation.

Simple visual analysis of the results indicates the "vertical" upgrading of the protected areas on the grassland units, so complex spatial analysis (Fig. 4) and statistical analysis (Table 3) were required to determine the type and weight of each entity in the combination of "preservation programmes".

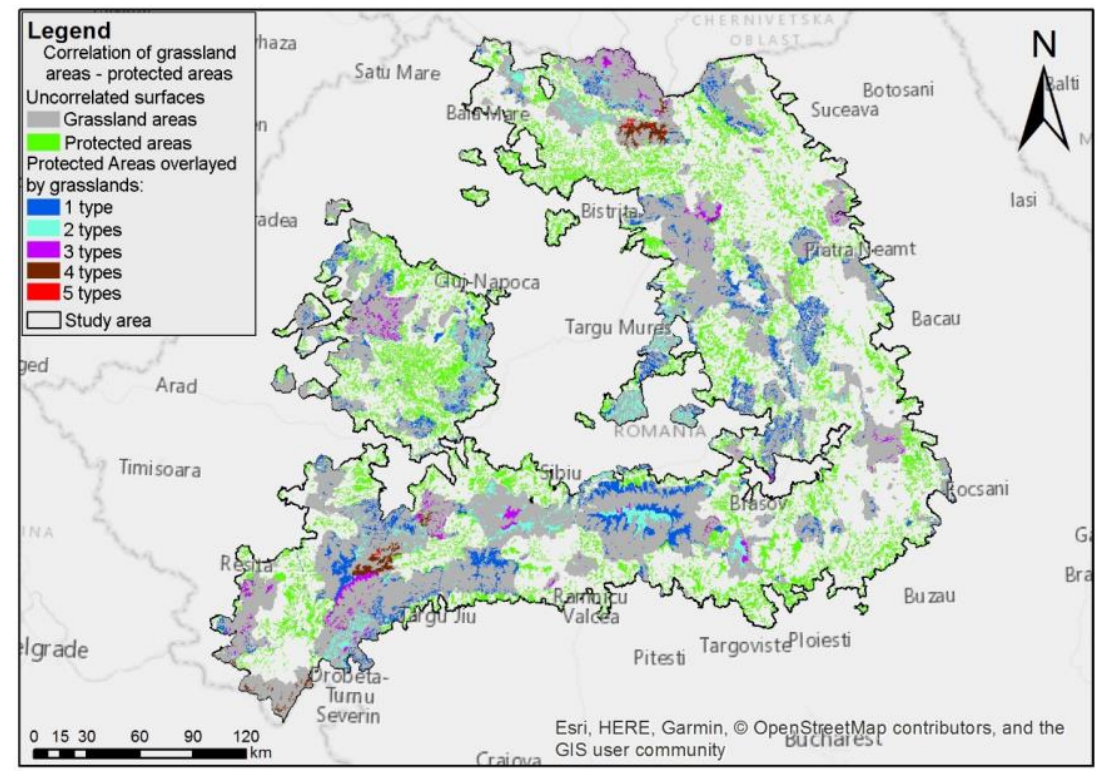

Figure 4. The correlation of grassland areas with protected areas. (processing after EEA, 2012; Ministry of the Environment, 2017; MARD, 2019)

From the analysis of the data synthesized in Figure 4 and Table 3, we may remark the following aspects:

- the grasslands are associated only with $27.77 \%$ SCIs and SPAs only, $22.96 \%$, these two being the most common in overlapping.

- NP is associated, in most cases, with Natura 2000 sites.

- of the total area of grasslands located in protected areas, there are $15.19 \%$ both SCI and SPA areas.

- as share, after SCI and SPA, NP comes into association with other protected areas, in proportions of approx. $5 \%$ in each case.

- the grasslands analyzed do not overlap with the category M.N. 
Table 3. Relationship grassland areas - categories of protected areas

\begin{tabular}{|c|c|c|c|c|c|c|c|c|c|c|c|c|}
\hline \multirow{2}{*}{ No. of P.A. entities } & \multicolumn{10}{|c|}{ Category of protected areas* } & \multicolumn{2}{|c|}{ Affected surface of grasslands*** } \\
\hline & $\mathbf{A}$ & $\mathbf{B}$ & $\mathbf{C}$ & $\mathbf{D}$ & $\mathbf{E}$ & $\mathbf{F}$ & $\mathbf{G}$ & $\mathbf{H}$ & $\mathbf{I}$ & $\mathbf{J}$ & ha & $\%$ \\
\hline \multirow{6}{*}{1} & & & & & & & & & & & 162203.66 & 27.77 \\
\hline & & & & & & & & & & & 980.39 & 0.17 \\
\hline & & & & & & & & & & & 7.72 & 0.00 \\
\hline & & & & & & & & & & & 25923.69 & 4.44 \\
\hline & & & & & & & & & & & 1686.10 & 0.29 \\
\hline & & & & & & & & & & & 134094.99 & 22.96 \\
\hline \multirow{12}{*}{2} & & & & & & & & & & & 12807.88 & 2.19 \\
\hline & & & & & & & & & & & 6704.55 & 1.15 \\
\hline & & & & & & & & & & & 36944.76 & 6.33 \\
\hline & & & & & & & & & & & 1291.88 & 0.22 \\
\hline & & & & & & & & & & & 88722.75 & 15.19 \\
\hline & & & & & & & & & & & 30.00 & 0.01 \\
\hline & & & & & & & & & & & 11.60 & 0.00 \\
\hline & & & & & & & & & & & 6.51 & 0.00 \\
\hline & & & & & & & & & & & 119.05 & 0.02 \\
\hline & & & & & & & & & & & 0.56 & 0.00 \\
\hline & & & & & & & & & & & 389.22 & 0.07 \\
\hline & & & & & & & & & & & 8.27 & 0.00 \\
\hline \multirow{10}{*}{3} & & & & & & & & & & & 21.31 & 0.00 \\
\hline & & & & & & & & & & & 6.83 & 0.00 \\
\hline & & & & & & & & & & & 4986.35 & 0.85 \\
\hline & & & & & & & & & & & 121.16 & 0.02 \\
\hline & & & & & & & & & & & 7938.05 & 1.36 \\
\hline & & & & & & & & & & & 10.04 & 0.00 \\
\hline & & & & & & & & & & & 478.23 & 0.08 \\
\hline & & & & & & & & & & & 31892.56 & 5.46 \\
\hline & & & & & & & & & & & 23886.57 & 4.09 \\
\hline & & & & & & & & & & & 0.17 & 0.00 \\
\hline \multirow{8}{*}{4} & & & & & & & & & & & 4530.49 & 0.78 \\
\hline & & & & & & & & & & & 30.28 & 0.01 \\
\hline & & & & & & & & & & & 5244.40 & 0.90 \\
\hline & & & & & & & & & & & 2069.25 & 0.35 \\
\hline & & & & & & & & & & & 27971.18 & 4.79 \\
\hline & & & & & & & & & & & 14.48 & 0.00 \\
\hline & & & & & & & & & & & 4.22 & 0.00 \\
\hline & & & & & & & & & & & 15.47 & 0.00 \\
\hline \multirow{4}{*}{5} & & & & & & & & & & & 62.24 & 0.01 \\
\hline & & & & & & & & & & & 2884.49 & 0.49 \\
\hline & & & & & & & & & & & 1.12 & 0.00 \\
\hline & & & & & & & & & & & 2.20 & 0.00 \\
\hline
\end{tabular}

Legend: A.P.-Protected area; *Protected area category: A - Natural Reserves from IUCN IV Category (NR), B - Monuments of Nature (MN), C - Special Protection Areas (SPA), D - National Parks (NP), E - Scientific Reserves (SR), F - Wetland of International Importance (RORMS), G - Natural Parks (np), H - Natural Reserves (RONPA), I - Biosphere Reserves (ROMAB), J - Sites of Community Importance (SCI); colored boxes suggest the presence of the protected area; **The figure 0.00 from the column „Affected surface of grasslands" designates surfaces with a percentage of less than $0.001 \%$

The data presented above shows the biological complexity of the Romanian mountainous area, also acknowledged at European level (Mráz and Ronikier, 2016), given by the large number of protected areas (770 entities) and implicitly by the species they protect, irrespective of their location or overlapping. 
Therefore, maintaining biodiversity is done through protection measures imposed by the presence of protected areas, but with the association of other independent or functionally related mechanisms: the continuous use of traditional practices, the fact that a substantial part of the region is represented by high nature value agricultural land (Babai and Molnár, 2014) and CAP measures, which will be described below.

\section{Strategies and measures of the Common Agricultural Policy (CAP) applied in the mountain area}

The European Union's rural development policy, introduced as the second pillar of the CAP through the Agenda 2000 reform, is co-financed by the European Agricultural Fund for Rural Development (EAFRD) and regional or national funds and was designed to "stimulate" the development of rural areas, with new economic, social and environmental approaches (European Parliament, 2019).

The rural development policy is implemented on the basis of rural development programs designed by the Member States (or their regions). These multiannual programs implement a personalized strategy that responds simultaneously to the specific needs of Member States (or regions). These programs are based on a combination of measures chosen from a "menu" of European measures detailed in the Rural Development Regulation (Regulation (EU) No 1305/2013) and co-financed by the EAFRD (according to the documentation of the Second pillar of the Common Agricultural Policy: rural development policy).

As the present study focuses on the grasslands in the mountainous area of Romania, only the programs that apply to this segment of agriculture (Regulation (EU) No 1307/2013) will be described in the following.

The preservation of high nature value (HNV) agricultural land is essential in the mountain area, for which the NRDP of Romania has introduced and promoted financial support activities and schemes to farmers in HNV areas through the agri-environment and climate measure. Figure 5 provides descriptive information on the financing strategies applicable to the land used as grassland and the areas where they are applied.

According to the data from the NRDP 2014 - 2020 (MARD, 2019), on approx. 95\% of the mountainous area can be used for agro-environment and climate programs and $5 \%$ of the area can also be accessed by programs dedicated to Ecologic Agriculture (Fig. 5).

High natural value grasslands (HNVs) are spread throughout the mountain area, with funds being allocated to traditional agricultural practices as a compensatory measure for the natural limitation of land productivity due to the pedo-climatic features of the area or as a result of the operation of agricultural work with manual or animal force.

In the central area of the Eastern Carpathians are located grasslands that support the conservation of bird species (Crex crex), in Suceava County (ATU Solca), grasslands that ensure survival and support the preservation of butterflies (Maculinea sp.).

Starting from the idea of preserving biodiversity, supported by numerous european and regional research and structures, we consider high natural value grassland to be of great importance, as rural communities depend on the key components of biodiversity and of ecosystem services that are found in non-domestic habitats (Vîntu et al., 2011).

In the view of the European Environment Agency (EEA, 2002), high natural value lands are those areas of high biological diversity on which extensive agriculture is practiced (Öllerer, 2014), also supported by the Live Viva Grass (2019) portal, according to which, in the category of high value pastures natural areas include those 
areas where extensive agriculture is practiced, areas with extremely high levels of biodiversity: they support healthy soils and a large number of wild species.

Although between 1947 and 1990 Romania's agriculture was "intensified" under totalitarian policies (Sârbu et al., 2004), large areas of grasslands "survived" these practices, nowadays our country is among the European countries with the highest resources of grasslands rich in "wild" vegetation (Akeroyd and Page, 2011).

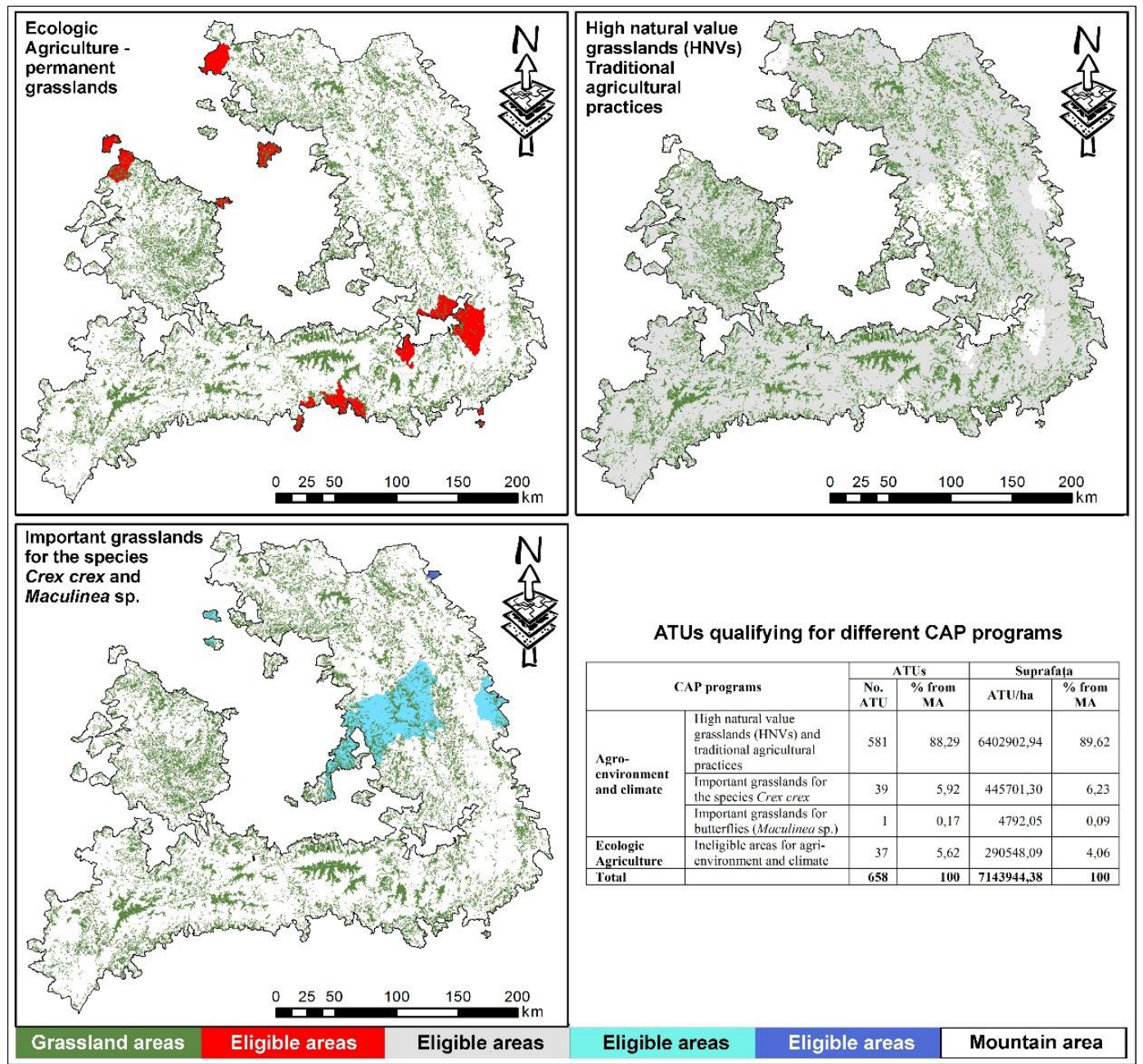

Figure 5. Classification of Romania's mountainous area into the EU's CAP financing programs. (processing after MARD, 2019, list of eligible areas)

Accessing programs primarily aimed at preserving the biodiversity of habitats and grassland species requires compliance with the requirements for their exploitation in conditions of sustainable "environmentally friendly" agriculture. Considering the fact that a large proportion of the owners and users of grasslands (HNV) in the mountainous area of Romania can receive subsidies through the Agro-Environment and Climate Program (MARD, 2019), these must comply with the conditions imposed by this program on grassland exploitation (Table 4).

Among the measures for preserving biodiversity of habitats and species, there is an emphasis on the idea of reducing or eliminating the use of chemical fertilizers. If we analyze the history of Romanian agriculture, chemical fertilization has been for a long 
time the "immediate" lever for increasing productivity. Starting from this concept, it is understood that reducing chemical fertilization leads to reduced productivity, but scientific research shows that for high natural value meadows the production of biomass is not affected by the depletion of soil in nutrients (Miladkova et al., 2015).

Table 4. Agro-environmental and climate requirements for grassland exploitation*

\begin{tabular}{|c|c|c|c|c|}
\hline \multirow[b]{2}{*}{$\begin{array}{c}\text { Conditions imposed } \\
\text { under the subsidized } \\
\text { programs }\end{array}$} & \multicolumn{4}{|c|}{ Agro-environment and climate } \\
\hline & $\begin{array}{l}\text { High natural value } \\
\text { grasslands (HNV) }\end{array}$ & $\begin{array}{c}\text { Traditional } \\
\text { agricultural } \\
\text { practices }\end{array}$ & $\begin{array}{l}\text { Grasslands that } \\
\text { support the } \\
\text { conservation of bird } \\
\text { species - Crex crex }\end{array}$ & $\begin{array}{l}\text { Grasslands that } \\
\text { support the } \\
\text { conservation of } \\
\text { butterfly species } \\
\text { (Maculinea } \text { sp.) }\end{array}$ \\
\hline It is necessary & $\begin{array}{c}\text { - the traditional use of } \\
\text { manure is allowed up to } \\
\text { the equivalent of a } \\
\text { maximum of } 40 \mathrm{~kg} \mathrm{~N} \\
\text { n.c./ha, } \\
\text { - maximum } 1 \mathrm{UVM} \text { per } \\
\text { hectare, } \\
\text { - mowing begins after } \\
\text { July } 1 \text { (UATs with } \\
\text { average altitudes above } \\
600 \text { m) or after June } 15 \\
\text { (UAT below } 600 \mathrm{~m} \\
\text { altitude) } \\
\text { - compliance with the ban } \\
\text { on manure application, } \\
\text { - not to apply organic or } \\
\text { mineral fertilizers to } \\
\text { protective strips. }\end{array}$ & - & $\begin{array}{c}\text { - mowing the } \\
\text { meadows after July } 31 \text {, } \\
\text { from the inside of the } \\
\text { plot to the outside, } \\
\text { - maximum } 0,7 \text { UVM } \\
\text { per hectare, } \\
\text { - the traditional use of } \\
\text { manure is allowed up } \\
\text { to the equivalent of a } \\
\text { maximum of } 40 \mathrm{~kg} \mathrm{~N} \\
\text { n.c./ha, } \\
\text { - a 3-meter-long, non- } \\
\text { mowed strip will be } \\
\text { left on the edges of } \\
\text { each plot (can be } \\
\text { mown after 1.09), } \\
\text { - compliance with the } \\
\text { ban on manure } \\
\text { application. }\end{array}$ & $\begin{array}{l}\text { - the traditional use } \\
\text { of manure is allowed } \\
\text { up to the equivalent of } \\
\text { a maximum of } 40 \mathrm{~kg} \mathrm{~N} \\
\text { n.c./ha, } \\
\text { - mowing after } 25.08 \text {, } \\
\text { - grazing is carried out } \\
\text { with a maximum of } 0.7 \\
\text { UVM per hectare }\end{array}$ \\
\hline It is forbidden & $\begin{array}{l}\text { - fertilizer and pesticide } \\
\text { administration, } \\
\text { - groundwater pollution } \\
\text { through spillage. }\end{array}$ & $\begin{array}{l}\text { - works with } \\
\text { mechanized } \\
\text { machinery, } \\
\text { - groundwater } \\
\text { pollution through } \\
\text { spillage. }\end{array}$ & $\begin{array}{c}\text { - works with } \\
\text { mechanized } \\
\text { machinery, } \\
\text { - actions to accelerate } \\
\text { natural drainage, } \\
\text { - fertilizers and } \\
\text { pesticides, } \\
\text { - groundwater } \\
\text { pollution through } \\
\text { spillage. }\end{array}$ & $\begin{array}{c}\text { - fertilizers and } \\
\text { pesticides, } \\
\text { - works with } \\
\text { mechanized } \\
\text { machinery, } \\
\text { - actions to accelerate } \\
\text { natural drainage, } \\
\text { - groundwater } \\
\text { pollution through } \\
\text { spillage }\end{array}$ \\
\hline
\end{tabular}

Legend: UVM-large cow unit, * data synthesized according to MARD, 2019

\section{Overlay of grassland areas covered by CAP policies with different protected area categories}

Of the total surface area of the grasslands in the mountainous area of Romania, $36.65 \%$ is covered by different categories of protected areas (Table 3, Fig. 4).

The data from the literature show that the Natura 2000 sites as well as the other categories of protected areas in the Carpathians are also found in the HNV regions (Akeroyd and Page, 2011). In order to identify grasslands covered by protected areas but also eligible for different CAP strategies, applied the multilayer analysis (Fig. 6).

As a result of the spatial correlations, more than $90 \%$ of the grasslands located in protected areas are also classified as high natural value (HNV) land used by traditional practices, and over approx. $8 \%$ of the "protected" grasslands meet the optimal conditions for the Crex crex species (Fig. 6). 
Natura 2000 sites, a pan-european network for nature conservation, also include in Romania priority habitats at community level which required their preservation by setting up Special Areas of Conservation (SAC): SPA sites (established by Romanian Government Decision no. 1284/2007) and SCI sites (set up by the Order of the MMDD no. 776/2007, Romanian Government Decision no. 971/2011).

Natura 2000 sites require special management (Cojocariu et al., 2017) but do not prohibit lucrative activities in favor of grassland biodiversity conservation and seek the adoption of sustainable solutions.

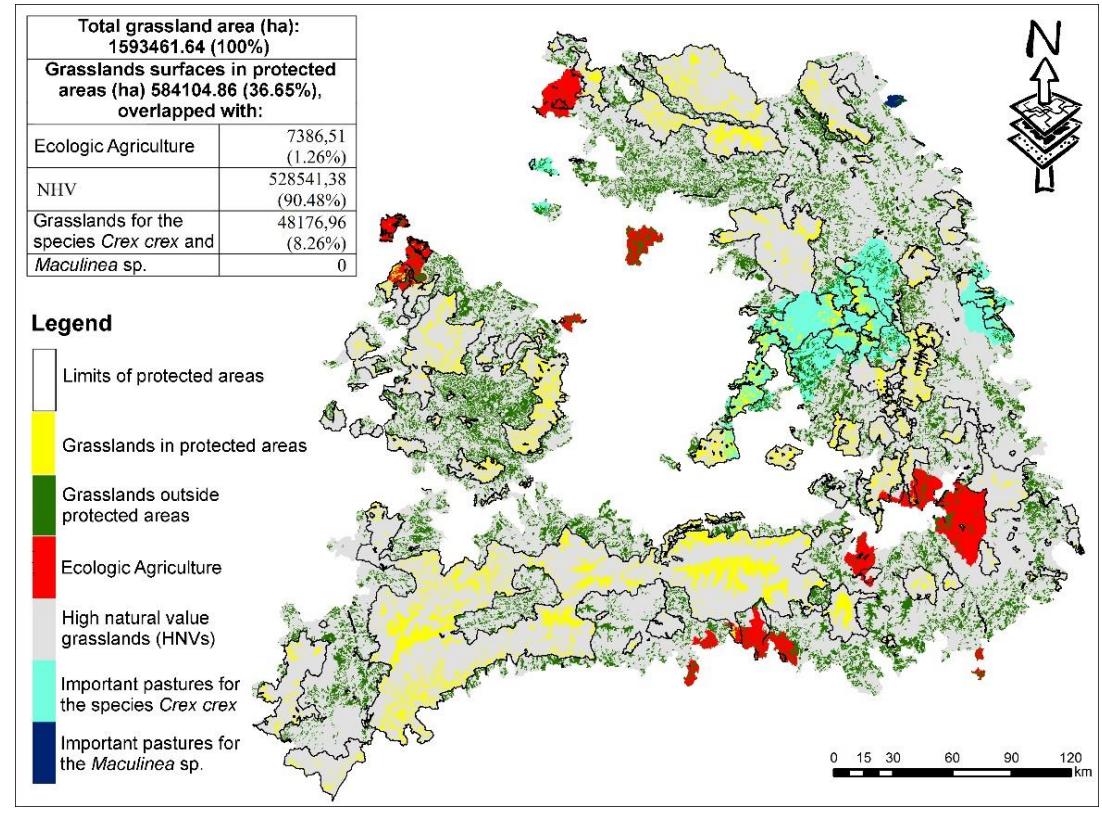

Figure 6. The correlation of grasslands in protected areas - EU CAP programs. (processing after Ministry of the Environment, 2017; MARD, 2019)

In order to encourage farmers managing agricultural land within the areas designated as Natura 2000 sites, financial support is expected from Pillar II of the CAP to compensate for the losses suffered.

In addition to the ecoconditionality measures for HNVs summarized in Table 4, mountain grassland users are also required to comply with a set of minimum conservation measures provided for in the management plan and regulation of the protected area over which they overlap.

Grassland management in protected areas aims to maintain the surface and grassland quality through active management for habitat and species conservation (Table 5).

In addition to the general and specific best practice measures for each site, recommended by the management plan, a series of awareness-raising, information and environmental education activities are required in collaboration with local communities and other stakeholders. It is also necessary to inform local communities about the existence and the process of compensation, through EU measures, for the disadvantages suffered by farmers in the mountain area. Therefore, incentives through Agro-Medium, Natura 2000 and conservation projects funded by public funds are very important in preventing mountain abandonment and biodiversity degradation, in the use of ecosystem services and preservation of cultural landscapes (Akeroyd and Page, 2011) 
by rural communities. The presence of several instruments can have synergistic effects (Sutcliffe et al., 2015) on the conservation of semi-natural habitats of mountain grasslands. This beautiful mountainous area of Romania still has many natural values that can be promoted and included in the strategies and programs of local communities' development.

Table 5. Minimum conservation measures in pastures superposed on protected areas

\begin{tabular}{|c|c|}
\hline & General measures \\
\hline \multirow{7}{*}{ It is necessary } & $\begin{array}{c}\text { Compliance with the management plan and area regulation with regard to surface use and pastoral } \\
\text { activities. }\end{array}$ \\
\hline & $\begin{array}{c}\text { Maintaining grassland habitats in good conservation status, through grazing and mowing, } \\
\text { respecting animal load and grazing and mowing periods. }\end{array}$ \\
\hline & $\begin{array}{l}\text { Ensure the conditions necessary to maintain the favorable conservation status of grassland habitats } \\
\text { as naturally as possible. }\end{array}$ \\
\hline & $\begin{array}{l}\text { Ensure the conditions necessary to maintain the favorable conservation status of grassland habitats } \\
\text { as naturally as possible. }\end{array}$ \\
\hline & $\begin{array}{c}\text { Maintaining biodiversity to ensure ecological balance of ecosystems and optimal conditions for } \\
\text { protected species. }\end{array}$ \\
\hline & $\begin{array}{l}\text { Preventing the spread and reducing the spread of invasive species on the territory of the protected } \\
\text { area. }\end{array}$ \\
\hline & Ensuring the necessary conditions for wild fauna species dependent on grassland habitats. \\
\hline \multirow{5}{*}{ It is forbidden } & $\begin{array}{l}\text { Intentional killing or capture of wild birds that make their nest in the shrub / trees in the } \\
\text { grasslands. }\end{array}$ \\
\hline & Damage, destruction of nests and / or harvesting of eggs from nature. \\
\hline & Deliberate disturbance of wild birds. \\
\hline & Damage and/or destruction of breeding or resting places of wild animals. \\
\hline & $\begin{array}{c}\text { Harvesting flowers and fruits, harvesting, cutting, uprooting or deliberately destroying wild plants } \\
\text { in their natural habitats. }\end{array}$ \\
\hline
\end{tabular}

\section{Conclusions}

The grasslands cover $22.30 \%$ (1593461.64 ha) of the surface area of Romania's mountainous area, a percentage which gives them a special importance for the mountain population being the natural resource with a multifunctional exploitation potential, realizable according to the conditions of sustainable agriculture, traditional practices.

The large number of identified protected areas (770 entities of different categories) support the idea of the high biodiversity of the mountainous area, implicitly of the grassland habitats.

One third of grassland areas (36.65\%) are included in one or more environmental protection structures; which again reveals the complexity of ecosystems: the existence of several protected areas overlapping on the same territory means the presence and protection of distinct habitats.

In addition to biodiversity conservation measures imposed by different protected areas, Romania's mountainous area is fully included in the Agro-Environment and Climate and Ecological Agriculture programs, part of the CAP, which encourages the pursuit of sustainable agriculture, also the protection of biological resources. The grasslands, one of the main economic resources of the mountain range, from the point of view of technological restraints, is suitable for a management or extensive management.

The present study, through scientific arguments, promotes and supports the Common Agricultural Policies, adopted at European level and implicitly in Romania, for a 
particularly important area in ecological, political, economic, geographical terms, both for Romania and at European level.

Encouraging and sustaining extensive traditional agricultural practices determines both the maintenance of biodiversity and the diversity of semi-natural grassland habitats. In addition to the environmental component, the financial support of grassland owners or users (HNV) also includes a socio-economic component. This is to be understood as an opportunity to obtain income from the inhabitants of these areas as a result of the marketing of agri-food products under the name of "mountain product" (Order no. 31/31.01.2018). This capitalization can be done either in a stand-alone activity or in integrated activities such as agro-tourism.

\section{REFERENCES}

[1] Akeroyd, J., Page, N. (2011): Conservation of High Nature Value (HNV) grassland in a farmed landscape in Transylvania, Romania. - Contributii Botanice 46: 57-71.

[2] Antonescu, D., Dumitrascu, M., Geacu, S., Grigorescu, I. (2015): Overview and perspectives of protected natural areas in Romania. - MPRA Paper 68317, University Library of Munich, Germany.

[3] Babai, D., Molnár, Zs. (2014): Small-scale traditional management of highly species-rich grasslands in the Carpathians. - Agriculture, Ecosystems and the Environment (in press).

[4] Baessler, C., Klotz, S. (2006): Effects of changes in agricultural land-use on landscape structure and arable weed vegetation over the last 50 years. - Agriculture, Ecosystems \& Environment 115: 43-50.

[5] Balázsi, Á. (2017): Grassland Management in Protected Areas: A Study on the Implementation of the EU Biodiversity Strategy in Certain Post-Communist Countries. Hacquetia.

[6] Bălteanu, D., Dumitrașcu, M., Ciupitu, D. (2009): România, Ariile naturale protejate, Harta 1:750000. - Editura CD Press, București.

[7] Căluşeru, L. A., Cojocariu, L., Borlea, F., Bordean, D. M., Horablaga, A. (2015): Rural development of mountain areas in Romania, challenges and targets for the year 2020. SGEM 5(2): 791-798.

[8] Ceballos, G., Davidson, A., List, R., Pacheco, J., Manzano-Fischer, P., Santos-Barrera, G., Cruzado, J. (2010): Rapid decline of a grassland system and its ecological and conservation implications. - PloS one 5(1): e8562. doi:10.1371/journal.pone.0008562.

[9] Cojocariu, L., Căluşeru, A., Horablaga, A., Bostan, C., Bordean, D. M. (2017): Evolution of the development and management of grasslands from Timiș, Romania, included in the ecologic Natura 2000 network. - SGEM 17(54): 307-314.

[10] Cojocariu, L., Bordean, D. M., Copacean, L., Hoancea, L. (2018): Evaluation of the biodiversity protection degree in Romanian Banat by geomatic methods. - SGEM 18(5.1): 369-376.

[11] Dumitraşcu, M., Grigorescu, I., Năstase, M., Dumitraşcu, C. (2015): Sustainable natural landscape management in the Romanian Carpathians. - Recent Advances in Fluid Mechanics and Heat \& Mass Transfer: 325-332.

[12] ESRI. Documentation for ArcMap, ArcGIS Desktop. - provided by ESRI. Available at: https://desktop.arcgis.com/en/documentation/.

[13] European Environment Agency (EEA) (2002): High Nature Value Farming Areas, Defining the concept and developing an agri-environmental indicator. - Proceedings of an Expert Meeting 21-22 February 2002, Copenhagen, Annex VI HNV expert meeting proceedings - www.eea.europa.eu/about-us/tenders/.../annex_06. 
[14] European Environment Agency (EEA) (2012): Corine Land Cover Database, 2012 Edition. - https://www.eea.europa.eu/data-and-maps/data/external/corine-land-cover2012.

[15] European Environment Agency (EEA) (2017): Digital Elevation Model (DEM) with spatial resolution at $25 \mathrm{~m}$, Produced using Copernicus data and information funded by the European Union. - EU-DEM layers; owned by the Enterprise and Industry DG (DGENTR) and the European Commission. Available at:

https://www.eea.europa.eu/data-and-maps/data/copernicus-land-monitoring-service-eudem.

[16] European Parliament (2019): Second pillar of the CAP: rural development policy, Fact Sheets on the European Union. Available at: http://www.europarl.europa.eu/factsheets/en/sheet/110/al-doilea-pilon-al-pac-politica-dedezvoltare-rurala.

[17] Food and Agricultural Organisation of the United Nation (FAO) (2010): Global Forest Resources Assessment, Main report, 2010. - Rome, Italy, 2010. Available at: http://www.fao.org/3/a-i1757e.pdf.

[18] Garnier, E., Lavorel, S., Ansquer, P., Castro, H., Cruz, P., Dolezal, J., Eriksson, O., Fortunel, C., Freitas, H., Golodets, C., Grigulis, K., Jouany, C., Kazakou, E., Kigel, J., Kleyer, M., Lehsten, V., Lepš, J., Meier, T., Pakeman, R., Papadimitriou, M., Papanastasis, V. P., Quested, H., Quétier, F., Robson, M., Roumet, C., Rusch, G., Skarpe, C., Sternberg, M., Theau, J-P., Thébault, A., Vile, D., Zarovali, M. P. (2007): Assessing the Effects of Land-use Change on Plant Traits, Communities and Ecosystem Functioning in Grasslands: A Standardized Methodology and Lessons from an Application to 11 European Sites. - Annals of Botany 99(5): 967-985.

[19] Geacu, S., Dumitrașcu, M., Maxim, I. (2012): The evolution of the natural protected areas Network in Romania. - Romanian Journal of Geography 56(1): 33-41.

[20] Google Earth platform (2018): Satellite images. - https://earth.google.com/web/.

[21] Iojă, C. I., Pătroescua, M., Rozylowicza, L., Popescu, V. D., Verghelețc, M., Zottac, M. I., Felciucc, M. (2010): The efficacy of Romania's protected areas network in conserving biodiversity. - Biological Conservation 143(11): 2468-2476.

[22] Lei, C., Lin, Z., Zhang, Q. (2014): The spreading front of invasive species in favorable habitat or unfavorable habitat. - J. Differ. Equ. 257: 145-166.

[23] Life Viva Grass (2019): High Nature Value Grasslands. - Available at: https://vivagrass.eu/grasslands/high-nature-value-grasslands/.

[24] López Lambas, M. E., Ricci, S. (2014): Planning and management of mobility in natural protected areas. - Procedia Soc. Behav. Sci. 162: 320-329.

[25] McDonald, R. I. (2013): Implications of Urbanization for Conservation and Biodiversity Protection. - In: Levin, S. A. (ed.) Encyclopedia of Biodiversity, 2nd ed. Academic Press: Amsterdam, The Netherlands, 231-244.

[26] Miladkova, P., Mladek, J., Hejduk, S., Hejcman, M., Cruz, P., Jouany, C., Pakeman, R. J. (2015): High-nature-value grasslands have the capacity to cope with nutrient impoverishment induced by mowing and livestock grazing. - Journal of Applied Ecology 52: 1073-1081.

[27] Ministry of Agriculture and Rural Development of Romania (MARD) (2019): The National Program for Rural Development 2014-2020. - Available at: http://www.madr.ro/docs/dezvoltare-rurala/2019/PNDR-2014-2020-versiunea-IXaprobata-23-ianuarie-2019.pdf.

[28] Ministry of the Environment (2000): National Strategy for the Conservation of Biodiversity. - Available at: http://www.mmediu.ro/img/attachment/32/biodiversitate54784ffea5918.pdf.

[29] Ministry of the Environment (2017): Geospatial database with protected area boundaries, information available in vector format, updated on 29.08.2017. - Available at: http://www.mmediu.ro/articol/date-gis/ 434. 
[30] Molnár, Z., Kis, J., Vadász, C., Papp, L., Sándor, I., Béres, S., Sinka, G., Varga, A. (2016): Common and conflicting objectives and practices of herders and conservation managers: the need for a conservation herder. - Ecosystem Health and Sustainability 2(4): e01215. doi: 10.1002/ehs2.1215.

[31] Mráz, P., Ronikier, M. (2016): Biogeography of the Carpathians: evolutionary and spatial facets of biodiversity. - Journal of the Linnean Society 119(3): 528-559.

[32] National Agency for Cadastre and Real Estate Advertising (NACRA) (2019): Geospatial vector data. - http://geoportal.ancpi.ro/geoportal/catalog/download/download.page.

[33] National Institute of Statistic of Romania (NIS) (2018): Surface area of the land fund by mode of use, by counties and localities. - Available at: http://statistici.insse.ro:8077/tempo-online/\#/pages/tables/insse-table.

[34] Order no. 776/2007 on the declaration of sites of Community importance as an integral part of the European ecological network Natura 2000 in Romania.

[35] Order no. 31/31.01.2018 amending the Annex to the Order of the Minister of Agriculture and Rural Development no. 52/2017 approving the Procedure for checking the conformity of the data contained in the tender dossier in order to grant the right of use of the "mountain product" option and to verify the compliance of the European and national legislation by the economic operators who have obtained the right of use of that mention. - published in the Official Gazette No 133/12.02.2018.

[36] Osterburg, B., Isermeyer, F., Lassen, B., Röder, N. (2010): Impact of economic and political drivers on grassland use in the EU. - Grassland Science in Europe 15: 14-28.

[37] Öllerer, K. (2012): The flora of the Breite woodpasture (Sighişoara, Romania). Brukenthal Acta Musei 7(3): 589-604.

[38] Öllerer, K. (2014): The ground vegetation management of woodpastures in Romania Insights in the past for conservation management in the future. - Applied Ecology And Environmental Research 12(2): 549-562.

[39] Păcurar, F., Rotar, I., Pleşa, A., Balázsi, Á., Vidican, R. (2015): Study of the Floristic Composition of Certain Secondary Grasslands in Different Successional Stages as a Result of Abandonment. - Bulletin USAMV series Agriculture 72(1): 193-201.

[40] Regulation (EU) No 1305/2013 of the European Parliament and of the Council of 17 december 2013, on support for rural development by the European Agricultural Fund for Rural Development (EAFRD) and repealing Council Regulation (EC) No 1698/2005. https://eur-lex.europa.eu/LexUriServ/LexUriServ.do?uri=OJ:L:2013:347:0487: 0548:EN:PDF.

[41] Regulation (EU) No 1307/2013 of The European Parliament and of the Council of 17 december 2013 establishing rules for direct payments to farmers under support schemes within the framework of the common agricultural policy and repealing Council Regulation (EC) No 637/2008 and Council Regulation (EC) No 73/2009. Available at https://eur-lex.europa.eu/LexUriServ/LexUriServ.do?uri=OJ:L:2013:347:0608: 0670:en:PDF.

[42] Romanian Government Decision no. 971 of 5 October 2011 for amending and completing the Government Decision no. 1.284 / 2007 on the declaration special avifauna protection areas as an integral part of the European ecological network Natura 2000 in Romania. Issuer: Government of Romania, Published in: Official Monitoring No. 715 of 11 October 2011 - http://www.mmediu.ro/beta/wp-content/uploads/2012/07/2012-07-25_legislatie_ arii_protejate_hg971din2011noispanatura2000.pdf.

[43] Romanian Government Decision no. 1284 of 24/10/2007 Published in the Official Gazette, Part I no. 739 of 31/10/2007, on the declaration of Special Aifaunistic Protection Areas as an integral part of the European ecological network Natura 2000 in Romania. https://www.osrgh.ro/pdf/hotarare-nr-1284-din-24-10-2007.pdf.

[44] Ruiz-Mallén, I., Corbera, E., Calvo-Boyero, D., Reyes-García, D. (2015): Participatory scenarios to explore local adaptation to global change in biosphere reserves: Experiences from Bolivia and Mexico. - Environ - Sci. Policy 54: 398-408. 
[45] Saraswati, G. (2014): Development Directives In Disaster-Prone Areas Based on Identification Level Vulnerability Using Geographical Information System Applications in Bogor Regency. - Procedia Soc. Behav. Sci. 135: 112-117.

[46] Sârbu, A., Coldea, G., Negrean, G., Cristea, V., Hanganu, J., Veen, P. (2004): Grasslands of Romania. Final report on National Grassland Inventory 2000-2003. - University of Bucharest \& Royal Dutch Society for Nature Conservation.

[47] Stanciu, E., Florescu, F. (2009): Ariile protejate din România, Noţiuni introductive, Editura „Green Steps”, Braşov.

[48] Sutcliffe, L., Akeroyd, J., Page, N., Popa, R. (2015): Combining approaches to support High Nature Value Farmland in southern Transylvania, Romania. - Hacquetia 14(1). DOI: $10.1515 /$ hacq-2015-0011.

[49] Vega, J. M., Díaz, A., Nava, J. M., Gallardo, M., Echavarría, P. (2017): Assessing Land Use-Cover Changes and Modelling Change Scenarios in Two Mountain Spanish National Parks. - Environments 4(4): 79.

[50] Vîntu, V., Samuil, C., Rotar, I., Moisuc, A., Razec, I. (2011): Influence of the management on the phytocoenotic biodiversity of some Romanian representative grassland types. - Not Bot Hort Agrobot Cluj 39(1): 119-125.

[51] Wandersee, S. M., An, L., López-Carr, D., Yang, Y. (2012): Perception and decisions in modeling coupled human and natural systems: A case study from Fanjingshan National Nature Reserve. - China. Ecol. Model. 229: 37-49. 